Agrovoc descriptors: Oryza sativa; rice; phosphorus; mineral deficiencies; crop yield; glomus mosseae; glomus intraradices; mycorrhizae; roots; flood irrigation

Agris category code: P34

\title{
Phosphorus mobilization and uptake in mycorrhizal rice (Oryza sativa L.) plants under flooded and non-flooded conditions
}

\author{
Roghieh HAJIBOLAND ${ }^{1}$, Naser ALIASGHARZAD ${ }^{2}$ and Robabeh BARZEGHAR ${ }^{3 *}$
}

Received August 14, 2008; accepted June 15, 2009.

Delo je prispelo 14. avgusta 2008, sprejeto 15. junija 2009.

\begin{abstract}
Phosphorus $(\mathrm{P})$ deficiency severely limits rice production in the world. Colonization of plant root with arbuscular mycorrhizal fungi (AMF) may have a considerable consequence for $\mathrm{P}$ uptake and plant growth. In contrast to other crop species, there is little experimental evidence about the role of mycorrhizal colonization in lowland rice plants. This study was undertaken to examine whether inoculation of rice plants can contribute in the mobilization and uptake of insoluble $\mathrm{P}$ form. In addition, an attempt was made to compare flooded plants with non-flooded ones in their mycorrhizal responsiveness. In one experiment, insoluble $\mathrm{P}$ was supplied for plants inoculated either with Glomus mosseae or Glomus intraradices, then growth and $\mathrm{P}$ uptake was determined. Results showed that colonization with AMF significantly improved uptake of $\mathrm{P}$ derived from insoluble $\mathrm{P}$ source. In other experiment, rice plants were inoculated with Glomus mosseae or Glomus intraradices in non-flooded nurseries and then transplanted either to flooded or non-flooded conditions. Root colonization by AMF was decreased due to flooding conditions from $43 \%$ to $27 \%$. Nevertheless, the plant growth responded positively $(117 \%$ increase) to inoculation when grown at flooded conditions, while dry matter of non-flooded plants was diminished up to $64 \%$ by inoculation. Mycorrhizal colonization had also a significant contribution in the uptake of $\mathrm{P}$ and $\mathrm{K}$ in flooded but not in non-flooded plants.
\end{abstract}

Key words: Glomus mosseae, Glomus intraradices, lowland rice, Oryza sativa, flooding

\section{IZVLEČEK}

\begin{abstract}
MOBILIZACIJA IN PRIVZEM FOSFORJA V RIŽU (Oriza sativa L.) V PRISOTNOSTI MIKORIZNIH GLIV S POPLAVNIM NAMAKANJEM IN BREZ LE-TEGA
\end{abstract}

Pomanjkanje fosforja $(\mathrm{P})$ omejuje svetovno pridelavo riža Naselitev rastlinskih korenin $\mathrm{z}$ arbuskularnimi mikoriznimi glivami (AMF) bi lahko pomembno vplivala na privzem $\mathrm{P}$ in rast rastlin. Poskusni podatki o vlogi mikorizne kolonizacije riževih rastlin so $\mathrm{v}$ primerjavi $\mathrm{z}$ nekaterimi drugimi vrstami rastlin redki. Ta raziskava je bila zastavljena, da bi proučili, ali inokulacija korenin riža $\mathrm{z}$ mikoriznimi glivami vpliva na mobilizacijo in privzem netopne oblike P. Mikorizna odzivnost je bila preizkušena $\mathrm{v}$ razmerah $\mathrm{z}$ in brez uporabe poplavnega namakanja. Netopna oblika $P$ je bila dodana rastlinam, inokuliranim $\mathrm{z}$ Glomus mosseae ali Glomus intraradices, opazovana je bila rast rastlin in privzem $\mathrm{P}$. Naselitev riževih korenin $\mathrm{z}$ AMF je vplivala na povečan privzem $\mathrm{P}$ iz netopnega vira tega elementa. $\mathrm{V}$ drugem poskusu so bile rastline inokulirane $\mathrm{z}$ istima vrstama mikoriznih gliv $\mathrm{v}$ nepoplavnih razmerah in nato presajene $\mathrm{v}$ poplavne in nepoplavne razmere. Naselitev korenin $\mathrm{z}$ AMF se je $\mathrm{v}$ poplavnih razmerah znižala s $43 \%$ na $27 \%$. Kljub temu je bil odziv rastlin na inokulacijo in izpostavitev poplavnim razmeram pozitiven, rast se je povečala za $117 \%$, medtem ko se je suha snov rastlin iz nepoplavnih razmer zmanjšala za $64 \%$. Inokulacija $\mathrm{z}$ mikoriznimi glivami je prav tako pomembno vplivala na privzem $\mathrm{P}$ in $\mathrm{K} \mathrm{v}$ poplavnih razmerah, tega vpliva pa ni bilo mogoče zaznati pri rastlinah $\mathrm{v}$ nepoplavnih razmerah.

Ključne besede: Glomus mosseae, Glomus intraradices, riž, Oryza sativa, poplavljanje

\footnotetext{
1 Associate Professor of Plant Science Department, University of Tabriz, Iran

2 Associate Professor of Soil Science Department, University of Tabriz, Iran

3 M.Sc. of Plant Physiology, University of Tabriz, Iran

* This paper is a part of the M.Sc. thesis of R.B. under supervision of R.H. and N.A.
} 


\section{INTRODUCTION}

The roots of most plant species are often colonized with arbuscular mycorrhizal fungi (AMF). The greatest beneficial effect of AMF symbiosis for host plant has been related to improved phosphorus $(\mathrm{P})$ nutrition. Root colonization with AMF can enhance the uptake of $\mathrm{P}$ by plant roots by providing a larger absorbing surface for uptake of $\mathrm{P}$ and by overcoming problems relating to development of depletion zone, via translocation in external hyphae to the host plant root (Peterso and Massicotte, 2004; Shenoy and Kalagudi, 2005). In addition to increased absorption surface in mycorrhizal root systems, mycorrhizal plants have been shown to have increased uptake of $\mathrm{P}$ from poorly soluble $\mathrm{P}$ sources, such as iron and aluminum phosphates and rock phosphate. Solubilization of soil $\mathrm{P}$ is achieved by rhizospheric modifications through the release of organic acids, phosphatase enzymes and some specialized metabolites like siderophores (Shenoy and Kalagudi, 2005). Indirect mechanisms deriving from the effects of AMF on rhizosphere properties have also been suggested. These include changes in $\mathrm{pH}$ ( $\mathrm{Li}$ et al., 2001) and root exudation patterns (Laheurte et al., 1990). Besides the direct effect of AMF on $P$ nutrition, uptake from soil of other mineral elements by the mycorrhizal mycelium and subsequent transfer to the plant have been demonstrated in particular for potassium (George et al., 1992) and nitrogen (George et al., 1995).

Rice is an important food crop particularly in Asia. Phosphorus deficiency is one of the most limiting factors in rice production and annually large amounts of $P$ fertilizers are being used in rice fields in the world (Itao et al., 1999). In contrast to other crop species such as clover (Nadian et al., 1997; Bi et al., 2003), sorghum (Bagayoko et al., 2000) and wheat (Hawkins and George, 1999), there is little experimental evidence about the role of mycorrhizal colonization in rice plants (Solaiman and Harita, 1996; Purakayastha and Chhonkar, 2001; Gao et al., 2007).

Although rice is grown in different ecosystems, 78\% of the world's rice is grown under irrigated or rainfed lowland conditions (Itao et al., 1999). It was reported that rice plants readily form mycorrhizal associations under upland conditions, but under submerged conditions infection is rare due to the anoxic environment (Ilag et al., 1987). Barea (1991) reported, however, that AMF can survive in waterlogged conditions, and this is supported by the fact that Glomus etunicatum, showed fairly high colonization in rice roots and best survival under submerged conditions (Purakayastha and Chhonkar, 2001). In a work on six aerobic rice genotypes, relatively high colonization of roots (28-57\% depending on genotypes) was observed (Gao et al., 2007) and significant effect on $\mathrm{Zn}$ uptake was reported. However, there is a paucity of information available on the involvement of AMF in mobilizing and uptake of $\mathrm{P}$ in rice particularly under waterlogged conditions.

Therefore, this work was aimed to investigate the effect of AMF colonization on mobilization of insoluble $\mathrm{P}$ form and P uptake. The second aim was to evaluate the effect of AMF colonization on growth and $\mathrm{P}$ uptake under flooded conditions compared with non-flooded colonized plants.

\section{MATERIAL AND METHODS}

\section{Preparation of substrate and fungal inoculum}

Quartz sand used as growth substrate was washed with tap water and treated with $1 \% \mathrm{HCl}$ for $24 \mathrm{~h}$. Then it was washed again once with tap water and 2 times with distilled water. After sterilization in autoclave for 2 hours and subsequent drying, quartz sand was weighed and then pots were filled.

The AMF species were Glomus mosseae (Nicol and Gerd) Gerdemann and Trappe or G. intraradices Schenck and Smith (provided by Soil Biology Laboratory, Faculty of Agricultural, University of Tabriz), that were propagated for 4 months on sorghum plants in greenhouse. Pot contents, including sand, root segments, hyphae and spores were used as inoculum. Number of spores in the inoculum was 33-35 per g for both of mycorrhizae species and root colonization percentages were 74.8 and 78.8 (\%) for G. mosseae and G. intraradices respectively.
Plant material, seed germination, nursery cultivation and transplantation

Rice (Oryza sativa L. cv. Shafagh) provided by Rice Research Center, Guilan, Iran, were surface-sterilized and then germinated in the dark on filter paper soaked with saturated $\mathrm{CaSO}_{4}$ solution. Germinated seeds were transferred to nursery culture including three treatments (without AMF inoculation, inoculation with G. mosseae, inoculation with $G$. intraradices) with three replicates per treatment. Nursery containers were filled with mixed sterilized sand and inoculum, then 30 young seedlings were transferred to each container and plants were grown for three weeks. Non-inoculated containers received the same amount of sterilized inoculum. Containers were irrigated with distilled water daily to maintain moisture at field capacity and were fed each week with half strength nutrient solution (Yoshida et al., 1972) without $\mathrm{P}$, but $\mathrm{Ca}_{3}\left(\mathrm{PO}_{4}\right)_{2}$ was added at 4 $\mathrm{g} \mathrm{Kg}^{-1}$ to each container. At the end of nursery culture, colonization of seedling roots was tested by random sampling. 


\section{Treatments and experimental design}

Colonized plants were transplanted to the $3 \mathrm{~L}$ pots and 5 plants were cultivated in each pot. Roots were carefully separated from rhizosphere soils and were washed with distilled water for removing soil particles before transplanting. Two separate experiments were conducted:

Experiment I. Three AMF treatments including without inoculation (-AMF), inoculation with $G$. mosseae or $G$. intraradices, four $\mathrm{P}$ treatments including without $\mathrm{P}, 0.05 \mathrm{mM}$ soluble $\mathrm{P}$ (as $\left.\mathrm{K}_{2} \mathrm{HPO}_{4}\right), 0.05 \mathrm{mM}$ insoluble $\mathrm{P}\left(\right.$ as $\left.\mathrm{Ca}_{3}\left(\mathrm{PO}_{4}\right)_{2}\right)$ and both $\mathrm{P}$ forms each at $0.05 \mathrm{mM}$ were applied in this experiment. Plants were grown under non-flooded conditions ( $60 \%$ of water holding capacity).

Experiment II. Three AMF treatments similar with Experiment I and two watering regime including flooded $(0.5$ $\mathrm{cm}$ water above the sand) and non-flooded and two $\mathrm{P}$ levels

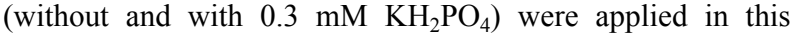
experiment.

Plants were grown for one month under controlled environmental conditions with a temperature regime of $25^{\circ} / 18^{\circ} \mathrm{C}$ day/night, $14 / 10 \mathrm{~h}$ light/dark period, a relative humidity of $70 / 80 \%$ and at a photon flux density of about 300 $400 \mu \mathrm{mol} \mathrm{m} \mathrm{s}^{-1}$. Plants were daily irrigated by distilled water or nutrient solution (Yoshida et al., 1972), the latter was performed after determination of nutrients depletion by measuring $\mathrm{N}$ and $\mathrm{P}$ concentrations in the pots.

\section{Harvest and analyses}

Harvested plants were first rinsed with tap water and then with distilled water. The mycorrhizal colonization percentage was evaluated by the grid line interest method (Phillips and Hayman, 1970). Shoots and roots were blotted dry on filter papers and dried at $70^{\circ} \mathrm{C}$ for 2 days to determine plant dry weight. For determination of elements content, oven-dried samples were ashed in a muffle furnace at $550^{\circ} \mathrm{C}$ for $8 \mathrm{~h}$ and then digested in 1:3 $\mathrm{HNO}_{3}$. The digested samples were dried on a heating plate and subsequently ashed at $550^{\circ} \mathrm{C}$ for another $3 \mathrm{~h}$. Samples were resuspended in $2 \mathrm{ml} 10 \% \mathrm{HCl}$ and made up to volume by double distilled water. Concentration of $\mathrm{P}$ was determined spectrophotometrically by ammoniumvanadate- molybdate method (Gericke and Kurmies, 1952) and of $\mathrm{K}$ was determined by flame photometry. Nutrient uptake was calculated for each pot as the sum of nutrient content of shoot and root for 5 plants.

Experiments were conducted in a randomized complete block design using three replications. Statistical analyses of data were carried out by ANOVA test (Tukey test at $\mathrm{p}<0.05$ ).

\section{RESULTS}

AMF colonization was not observed in the noninoculated plants. The highest colonization rate occurred in the absence of added $\mathrm{P}$ in both experiments. In Experiment I, presence of soluble and insoluble $\mathrm{P}$ reduced colonization of root by about $30-31 \%$ to $15-$ $16 \%$. Effect of soluble $\mathrm{P}$ form in lowering colonization of roots was greater than insoluble $\mathrm{P}$ form. The lowest colonization $(10 \%)$ was observed in the presence of both $\mathrm{P}$ forms (Table 1). In Experiment II, application of P lowered colonization from $43 \%$ to only $25 \%$ in nonflooded and from $27 \%$ to $15 \%$ in flooded plants inoculated with G. intraradices. Flooding had a significant inhibitory effect on colonization of roots, it resulted in reduction of colonization rate from $35-43 \%$ to $25-27 \%$ in $-\mathrm{P}$ and from $22-25 \%$ to $12-15 \%$ in $+\mathrm{P}$ plants (Table 2).

\section{Effect of inoculation on chlorophyll content and growth of plants}

Experiment I: Plants growth and chlorophyll content of leaves was significantly reduced when roots were inoculated with AMF. Growth inhibition of colonized plants was $28-60 \%$ compared with non-inoculated ones depending on AMF species and $\mathrm{P}$ supply form. Negative effect of AMF colonization was more prominent in plants inoculated with $G$. mosseae compared with plants colonized with $G$. intraradices and was similar for root and shoot. The highest plants growth was achieved at supply of soluble $\mathrm{P}$ and application of both $\mathrm{P}$ forms under non-inoculation conditions (Table 1).

Experiment II: The growth response of plants to colonization by AMF was greatly depended on flooding treatment. In flooded plants, in contrast to plants grown at non-flooded condition, AMF inoculation stimulated growth significantly (shoot and root dry weight). Plants height and chlorophyll content was also affected positively by AMF inoculation in flooded but not in non-flooded plants. The positive effect of AMF colonization on shoot and root dry weight of flooded plants was clearly depended on AMF species and the level of P. In $-\mathrm{P}$ plants, the positive effect of $G$. intraradices was mainly higher than $G$. mosseae, and in $+\mathrm{P}$ plants the trend was inverse (Table 2 ). 
Table 1. Leaf chlorophyll content and growth of rice (Oryza sativa L. cv. Shafagh) without (-AMF) and with inoculation by Glomus mosseae or Glomus intraradices supplied by different phosphorus form and grown under non-flooded conditions. Data in each column followed by the same letter are not different significantly $(P<0.05)$.

\begin{tabular}{|c|c|c|c|c|c|c|}
\hline$P$ & AMF & $\begin{array}{c}\text { Root } \\
\text { colonization( } \\
\%) \\
\end{array}$ & $\begin{array}{l}\text { Chlorophyll } \\
\text { (Relative) }\end{array}$ & $\begin{array}{l}\text { Plant Height } \\
(\mathrm{cm})\end{array}$ & $\begin{array}{l}\text { Shoot Yield } \\
\left(\mathrm{mg} \mathrm{pot}^{-1}\right)\end{array}$ & $\begin{array}{c}\text { Root Yield } \\
\left(\mathrm{mg} \mathrm{pot}^{-1}\right)\end{array}$ \\
\hline \multirow[t]{3}{*}{$-\mathrm{P}$} & $-\mathrm{AMF}$ & $0^{\mathrm{f}}$ & $100 \pm 3^{a}$ & $73 \pm 1^{b}$ & $2073 \pm 18^{b}$ & $890 \pm 12^{c}$ \\
\hline & G. $m$ & $31 \pm 3^{\mathrm{a}}$ & $42 \pm 3^{\mathrm{f}}$ & $38 \pm 3^{g}$ & $834 \pm 135^{f}$ & $410 \pm 37^{\mathrm{f}}$ \\
\hline & G. in & $30 \pm 1^{\mathrm{a}}$ & $63 \pm 8^{\mathrm{d}}$ & $50 \pm 1^{\mathrm{e}}$ & $1374 \pm 17^{\mathrm{d}}$ & $480 \pm 15^{\text {ef }}$ \\
\hline$+\mathrm{P}$ & $-\mathrm{AMF}$ & $0^{\mathrm{f}}$ & $88 \pm 5^{b}$ & $77 \pm 2^{a}$ & $2454 \pm 59^{a}$ & $1749 \pm 211^{a}$ \\
\hline \multirow{2}{*}{ (soluble) } & G. $m$ & $16 \pm 1^{\mathrm{c}}$ & $49 \pm 5$ ef & $45 \pm 3^{f}$ & $1328 \pm 72^{d}$ & $595 \pm 15^{\mathrm{de}}$ \\
\hline & G. in & $15 \pm 1^{\mathrm{c}}$ & $74 \pm 10^{\mathrm{c}}$ & $66 \pm 4^{c}$ & $1754 \pm 159^{\mathrm{c}}$ & $863 \pm 14^{\mathrm{c}}$ \\
\hline & $-\mathrm{AMF}$ & $0^{f}$ & $94 \pm 4^{\mathrm{ab}}$ & $72 \pm 1^{b}$ & $1817 \pm 70^{\mathrm{c}}$ & $877 \pm 10^{c}$ \\
\hline \multirow{2}{*}{ (insoluble) } & G. $m$ & $18 \pm 1^{b}$ & $42 \pm 3^{f}$ & $36 \pm 2^{h}$ & $1001 \pm 17^{\mathrm{e}}$ & $436 \pm 10^{\mathrm{f}}$ \\
\hline & G. in & $18 \pm 0^{\mathrm{b}}$ & $57 \pm 3$ de & $51 \pm 2^{\mathrm{e}}$ & $1309 \pm 56^{\mathrm{d}}$ & $503 \pm 26^{\text {ef }}$ \\
\hline$+\mathrm{P}$ & $-\mathrm{AMF}$ & $0^{\mathrm{f}}$ & $91 \pm 3^{b}$ & $77 \pm 2^{a}$ & $2321 \pm 83^{a}$ & $1614 \pm 59^{b}$ \\
\hline (Soluble + & G. $m$ & $12 \pm 1^{\mathrm{d}}$ & $42 \pm 3^{f}$ & $37 \pm 1^{\text {gh }}$ & $1270 \pm 54^{d}$ & $597 \pm 12^{\mathrm{de}}$ \\
\hline insoluble) & G. in & $10 \pm 1^{\mathrm{e}}$ & $72 \pm 3^{c}$ & $56 \pm 2^{d}$ & $1405 \pm 107^{\mathrm{d}}$ & $704 \pm 112^{d}$ \\
\hline
\end{tabular}

Table 2. Leaf chlorophyll content and growth of rice (Oryza sativa L. Cv. Shafagh) without (-AMF) and with inoculation by Glomus mosseae or Glomus intraradices supplied by different phosphorus level and grown under flooded or non-flooded conditions. Data in each column followed by the same letter are not different significantly $(P<0.05)$.

\begin{tabular}{|c|c|c|c|c|c|c|c|}
\hline $\mathrm{P}$ & $\begin{array}{l}\text { Flooded/ } \\
\text { Non- } \\
\text { flooded }\end{array}$ & AMF & $\begin{array}{c}\text { Root } \\
\text { colonization( } \\
\%) \\
\end{array}$ & $\begin{array}{c}\text { Chlorophyll } \\
\text { (Relative) }\end{array}$ & $\begin{array}{l}\text { Plant Height } \\
(\mathrm{cm})\end{array}$ & $\begin{array}{c}\text { Shoot Yield } \\
\left(\mathrm{mg} \mathrm{pot}^{-1}\right)\end{array}$ & $\begin{array}{c}\text { Root Yield } \\
\left(\mathrm{mg} \mathrm{pot}^{-1}\right)\end{array}$ \\
\hline \multirow[t]{3}{*}{$-\mathrm{P}$} & Flooded & $-\mathrm{AMF}$ & $0^{g}$ & $131 \pm 25^{a b}$ & $26 \pm 4.1^{b c}$ & $677 \pm 153^{c}$ & $269 \pm 84^{d}$ \\
\hline & & G. $m$ & $25 \pm 1^{\mathrm{c}}$ & $152 \pm 18^{a b}$ & $34 \pm 0.9^{\mathrm{ab}}$ & $1297 \pm 101^{b}$ & $1006 \pm 134^{b}$ \\
\hline & & G. in & $27 \pm 1^{\mathrm{c}}$ & $175 \pm 12^{\mathrm{a}}$ & $34 \pm 1.8^{\mathrm{ab}}$ & $1473 \pm 109^{b}$ & $1472 \pm 275^{\mathrm{a}}$ \\
\hline \multirow[t]{3}{*}{$+\mathrm{P}$} & Flooded & $-\mathrm{AMF}$ & $0^{g}$ & $100 \pm 2^{b}$ & $24 \pm 9.0^{b c}$ & $1171 \pm 231^{b}$ & $497 \pm 120^{\mathrm{cd}}$ \\
\hline & & G. $m$ & $12 \pm 2^{\mathrm{f}}$ & $128 \pm 7^{\mathrm{ab}}$ & $40 \pm 7.2^{\mathrm{a}}$ & $2580 \pm 319^{a}$ & $1538 \pm 249^{a}$ \\
\hline & & G. in & $15 \pm 1^{\mathrm{e}}$ & $126 \pm 18^{a b}$ & $34 \pm 0.6^{\mathrm{ab}}$ & $2209 \pm 311^{\mathrm{a}}$ & $1262 \pm 95^{\mathrm{ab}}$ \\
\hline \multirow[t]{3}{*}{$-\mathrm{P}$} & Non- & $-\mathrm{AMF}$ & $0^{g}$ & $192 \pm 27^{\mathrm{a}}$ & $37 \pm 5.5^{\mathrm{a}}$ & $1333 \pm 157^{b c}$ & $823 \pm 126^{c}$ \\
\hline & Flooded & G. $m$ & $35 \pm 2^{b}$ & $185 \pm 39^{a}$ & $26 \pm 1.3^{b c}$ & $699 \pm 48^{\mathrm{cd}}$ & $521 \pm 98^{\mathrm{cd}}$ \\
\hline & & G. in & $43 \pm 2^{a}$ & $188 \pm 12^{\mathrm{a}}$ & $25 \pm 1.3^{b c}$ & $481 \pm 82^{\mathrm{d}}$ & $367 \pm 96^{\mathrm{d}}$ \\
\hline \multirow[t]{3}{*}{$+\mathrm{P}$} & Non- & $-\mathrm{AMF}$ & $0^{\mathrm{g}}$ & $196 \pm 13^{a}$ & $40 \pm 0.3^{\mathrm{a}}$ & $2066 \pm 177^{a}$ & $1384 \pm 142^{\mathrm{ab}}$ \\
\hline & Flooded & G. $m$ & $22 \pm 1^{d}$ & $187 \pm 5^{\mathrm{a}}$ & $31 \pm 3.4^{\mathrm{ab}}$ & $1140 \pm 189^{b}$ & $1048 \pm 213^{b c}$ \\
\hline & & G. in & $25 \pm 1^{\mathrm{c}}$ & $142 \pm 42^{a b}$ & $29 \pm 1.3^{b c}$ & $856 \pm 153^{\mathrm{cd}}$ & $554 \pm 49^{\mathrm{cd}}$ \\
\hline
\end{tabular}

Flooding had an obvious effect on plants growth depending on mycorrhizal status. In non-mycorrhizal plants, flooding conditions reduced dry weight of shoot and root by about $43-48 \%$ and $64-67 \%$ respectively. Inoculation with AMF changed the plants growth response to flooding. Flooding improved shoot and root dry weight of mycorrhizal plants up to $86-206 \%$ in $-\mathrm{P}$ and $56-156 \%$ in $+\mathrm{P}$ treatments when inoculated with $G$. mosseae and $G$. intraradices respectively.

Nutrients uptake under inoculation and noninoculation conditions

Experiment I: P uptake was lower significantly or in tendency in mycorrhizal plants with the exception of plants supplied with insoluble $\mathrm{P}$ as the sole $\mathrm{P}$ source. In the latter treatment, a significant effect of mycorrhization was observed for P uptake only in plants colonized with G. mosseae. Potassium uptake was significantly lower in mycorrhizal plants under all $\mathrm{P}$ supply form and inoculation with both AMF species (Fig. 1).

Experiment II: A significant positive response of P uptake to inoculation was observed only in flooded plants inoculated with G. mosseae in both P treatments. In contrast, in plants at non-flooded conditions, $\mathrm{P}$ uptake was decreased slightly or significantly by AMF inoculation in both $\mathrm{P}$ treatments. Potassium uptake was slightly higher in flooded plants at both $\mathrm{P}$ treatments (Fig. 2). 


\section{固-AMF 图 G. mosseae 圆 G. intraradices}
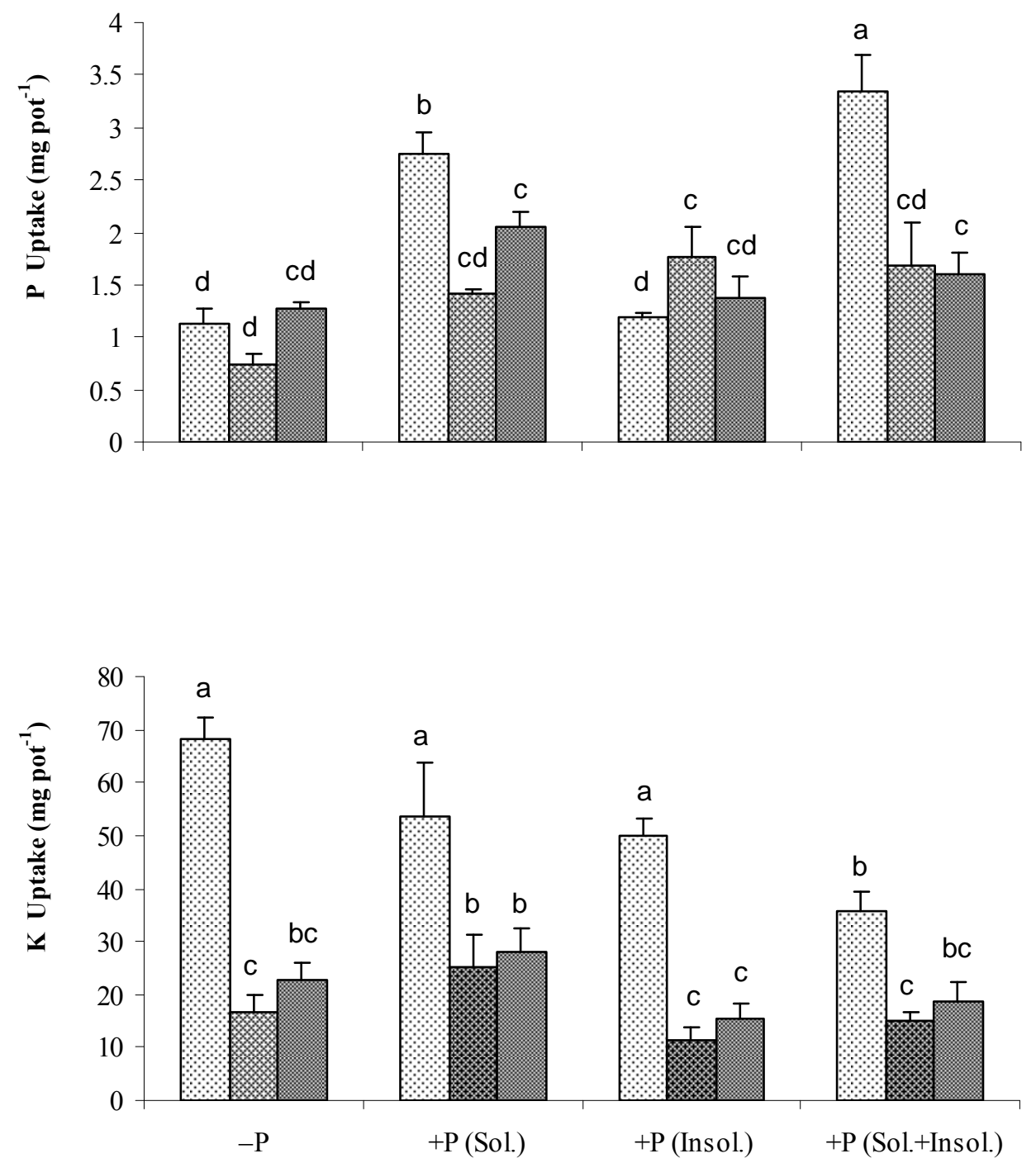

Treatments

Fig. 1. Uptake of $P$ and $K$ by rice (Oryza sativa L. cv. Shafagh) without (-AMF) and with inoculation by Glomus mosseae or Glomus intraradices supplied by different phosphorus form and grown under non-flooded conditions. Columns indicated by the same letter are not different significantly $(P<0.05)$ 


\section{ㅇ-AMF 图 G. mosseae 圆 G. intraradices}
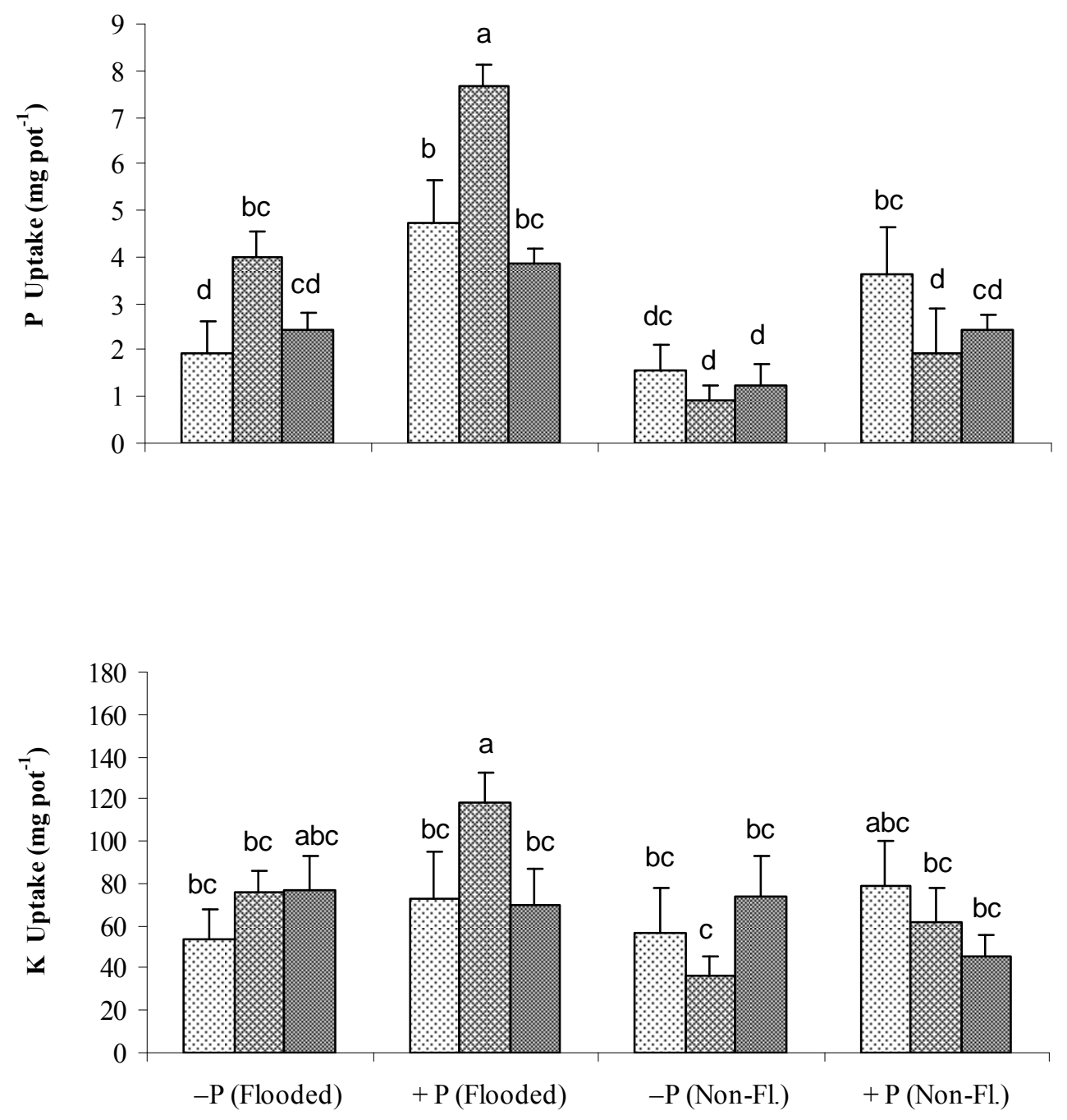

Treatments

Fig. 2. Uptake of $P$ and $K$ by rice (Oryza sativa L. CV. Shafagh) without (-AMF) and with inoculation by Glomus mosseae or Glomus intraradices supplied by different phosphorus level and grown under flooded or nonflooded conditions. Columns indicated by the same letter are not different significantly $(P<0.05)$. 

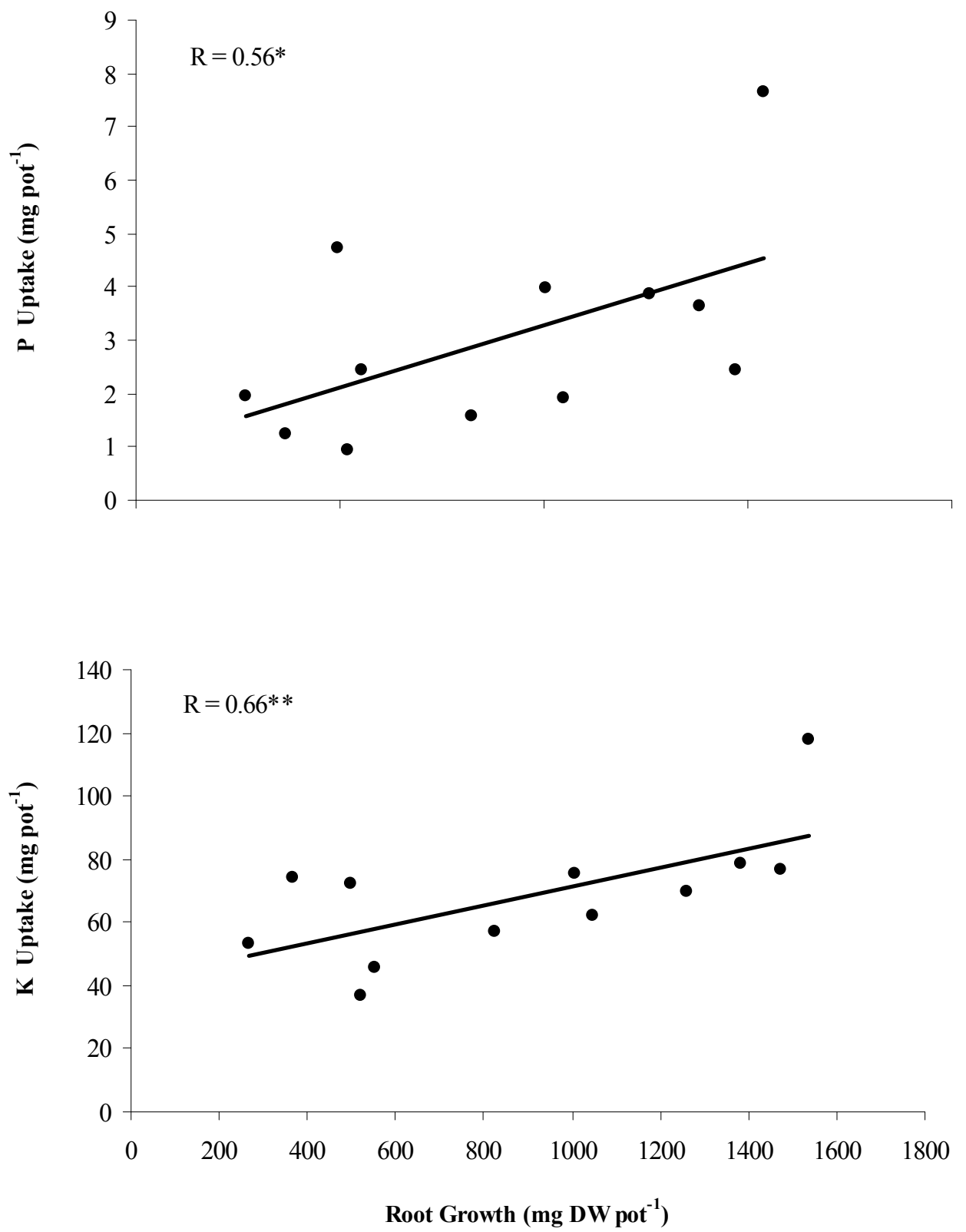

Fig. 3. The correlation between root growth $\left(\mathrm{mg} \mathrm{DW} \mathrm{pot}^{-1}\right)$ and uptake of $\mathrm{P}$ and $\mathrm{K}\left(\mathrm{mg} \mathrm{pot}^{-1}\right)$ in rice (Oryza sativa L. $\mathrm{CV}$. Shafagh) without or with inoculation by AMF. $R$ values followed by * or ** are significant at the 0.05 or 0.01 probability levels, respectively.

\section{DISCUSSION}

\section{Mycorrhizal colonization and plant growth}

Colonization of roots with AMF in plants grown nonflooded, reduced distinctly plants growth at all $\mathrm{P}$ treatments. It suggests that, AMF colonization reduces plant performance under non-flooded conditions independent from their $\mathrm{P}$ nutritional status. It is well known that the establishment and maintenance of mycorrhizal symbiosis is linked to a flow of carbon from the host plant to the fungus. Accordingly, a substantial proportion of photosynthates allocated to the roots, is required for symbiosis. Environmental conditions such as shading and defoliation, which limit photosynthates supply to plants also depress colonized plants growth (Marschner, 1995). Therefore, depression of plant yield in response to AMF colonization in this work, could be well explained by competition of fungus with plants for photosynthates, because of a low photosynthesis rate of plants, which is most likely due 
to a low light intensity in growth chamber (300-400

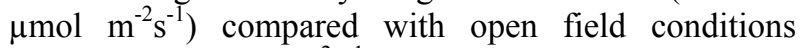

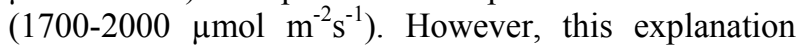
could not be applied for mycorrhizal plants under flooded conditions. The cause of different mycorrhizal responsiveness of flooded and non-flooded plants could not be interpreted by their flooding response when nonmycorrhizal. It is likely the result of a specific interaction between AMF and plants which is likely established only under flooded conditions. Whether the greater $\mathrm{P}$ and $\mathrm{K}$ uptake observed in flooded compared with non-flooded mycorrhizal plants is the cause or result of positive mycorrhizal responsiveness of flooded plants is not known and should be further investigated in detail.

The colonization rate of flooded plants at harvest was significantly lower than non-flooded plants. Because the colonization rate of roots was similar for plants before transplanting, the effect of different colonization rate of seedlings at the start of transplanting stage could be ruled out. Therefore, differential colonization of roots was most likely developed after transplantation and throughout the experiment due to submergence. AMF fungi are obligate aerobes, accordingly, a low colonization rate of roots under flooded conditions could be the result of lower oxygen availability to fungi. Nevertheless, it was reported that, the colonization of roots of rice with $G$. etunicatum in aerobic nursery conditions persisted under waterlogged conditions when the rice was transplanted (Purakayastha and Chhonkar, 2001). Difference among AMF species and plants genotype in their response to oxygen availability is one explanation of this discrepancy. However, in this work a significant benefit of host plants from AMF inoculation under flooded conditions was achieved though a low colonization.

\section{Effect of AMF inoculation on P uptake}

Mycorrhization of plants with $G$. mosseae caused a significant mobilization of insoluble $\mathrm{P}$ in the substrate and uptake by plants. Effect of $G$. intraradices was not significant. Mycorrhizal plants have increased uptake of $\mathrm{P}$ from poorly soluble $\mathrm{P}$ sources through either direct or indirect mechanisms deriving from the effects of AMF on rhizosphere properties including changes in $\mathrm{pH}$ ( $\mathrm{Li}$ et al., 2001) and root exudate patterns (Laheurte et al., 1990). We observed a significant acidification of rhizophere in mycorrhizal rice plants under low $\mathrm{P}$ supply that reached up to $1.7 \mathrm{pH}$ units (Hajiboland et al., 2007).

AMF colonization had also a significant effect on uptake of soluble $\mathrm{P}$ in flooded plants. In $\mathrm{P}$ deficient soils, root colonization by AMF, improved significantly $P$ uptake per unit root length due to the enhancement of the total root surface by hyphal growth (Smith and
Read, 1996). In addition of improvement of $P$ uptake per unit root length as the consequence of increased total root surface, one of the main causes of increased $\mathrm{P}$ uptake by inoculation and genotypic differences is the response of root growth to AMF. Increased $\mathrm{P}$ uptake was clearly associated with increased root growth e.g. root weight. Root dry weight was increased up to 274 and $209 \%$ in $-\mathrm{P}$ and $+\mathrm{P}$ flooded plants respectively inoculated with $G$. mosseae which was associated with 105 and $61 \%$ increase in $\mathrm{P}$ uptake of $-\mathrm{P}$ and $+\mathrm{P}$ plants respectively. The corresponding values for $\mathrm{K}$ uptake was 42 and $63 \%$ for $-\mathrm{P}$ and $+\mathrm{P}$ plants respectively. Conversely, root growth was inhibited by inoculation up to 24 and $37 \%$ in non-flooded $-\mathrm{P}$ and $+\mathrm{P}$ plants respectively, which results in reduction of $\mathrm{P}$ uptake up to $40-47 \%$ and $\mathrm{K}$ uptake by about $35-21 \%$ in $-\mathrm{P}$ and $+\mathrm{P}$ plants respectively. The contribution of root growth in increased nutrient uptake was reflected in the correlation coefficient (R) between root dry weight and $\mathrm{P}$ and $\mathrm{K}$ uptake (Fig. 3). Therefore, root growth response to AMF was a determining factor in the response of $\mathrm{P}$ and $\mathrm{K}$ uptake to AMF inoculation.

Reduction of $\mathrm{K}$ uptake due to AMF colonization observed in the Experiment I and in the non-flooded plants in the Experiment II could be also the result of an overall growth reduction particularly root growth and surface area in AMF inoculated plants. Root length and spatial availability are particularly important for nutrients such as $\mathrm{P}$ and $\mathrm{K}$ (Marschner, 1995), accordingly, $\mathrm{K}$ uptake responded similar with $\mathrm{P}$ to the changes in the root growth in this work. Uptake of $\mathrm{K}$ was reported to increase by AMF inoculation in some tropical plant species, cowpea and sorghum (Bagayoko et al., 2000), decrease in millet (Bagayoko et al., 2000) or remained unchanged in barley (Mohammad et al., 2003).

\section{Effect of AM colonization in dependence of AMF species}

Mycorrhizal species were different in their effect on growth and nutrient uptake. Although negative effect of AMF colonization on plant growth under non-flooded conditions (Experiment I) was more prominent in plants inoculated with $G$. mosseae compared with $G$. intraradices, effect of colonization with the former AMF species in mobilization and uptake of insoluble $\mathrm{P}$ form was higher than that with the latter species. Similarly, inoculation by G. mosseae, had a beneficial effect on $\mathrm{P}$ uptake under flooded but not non-flooded conditions. A poor effectivity of $G$. intraradices cannot be explained by lower root colonization. It might be related to poor development and activity of the external hyphae, low hyphal transport rates, and poor solute interchange at the arbuscule-host root cell interface (Marschner, 1995). 


\section{REFERENCES}

Bagayoko M., George E., Römheld V., Buerkert A. 2000. Effects of mycorrhizae and phosphorus on growth and nutrient uptake of millet, cowpea and sorghum on a West African soil. J. Agricultural Science, 135: 399-407.

Barea J.M. 1991. Vesicular-Arbuscular Mycorrhizae as Modifiers of Soil Fertility. Advances in Soil Science, 15: 1-40.

Bi Y.L., Li X.L., Christie P. 2003. Influence of early stages of arbuscular mycorrhiza on uptake of zinc and phosphorus by red clover from a lowphosphorus soil amended with zinc and phosphorus. Chemosphere, 50: 831-837.

Gao X., Kuyper T.W., Zou C., Zhang F., Hoffland E. 2007. Mycorrhizal responsiveness of aerobic rice genotypes is negatively correlated with their zinc uptake when nonmycorrhizal. Plant and Soil, 290: 283-291.

George E., Häussler K.U., Vetterlein D., Gorgus E., Marschner H. 1992. Water and nutrient translocation by hyphae of Glomus mosseae. Canadian Journal of Botany, 70: 2130-2137.

George E., Marschner H., Jakobson I. 1995. Role of arbuscular-mycorrhizal fungi in uptake of phosphorus and nitrogen from soil. Critical Reviews in Biotechnology, 15: 257-270.

Gericke S., Kurmies B. 1952. Die kolorimetrische Phosphorsäure-bestimmung mit AmmoniumVanadat-Molybdat und ihre Anwendung in der Pflanzenanalyse. Zeitschrift für Pflanzenernährung, Düngung und Bodenkunde, 59: 235-247.

Hajiboland R., Alisasgharzad N., Barzeghar R. 2007. Impacts of inoculation with two species of arbuscular mycorrhizae on rice (Oryza sativa L.) growth, $\mathrm{P}$ and $\mathrm{K}$ uptake and rhizosphere $\mathrm{pH}$. Iranian Journal of Soil and Water Sciences, 21: 111-121.

Hawkins H.J., George E. 1999. Effect of plant nitrogen status on the contribution of arbuscular mycorrhizal hyphae to plant nitrogen uptake. Physiologia Plantarum, 105: 694-700.

Ilag L.L., Rosales A.M., Elazegvi F.V., Mew T.W. 1987. Changes in the population of infective endomycorrhizal fungi in a rice based cropping system. Plant and Soil, 103: 67-73.

Itao E., Ella E., Kawanto N. 1999. Physiological basis of submergence tolerance in rainfed lowland rice ecosystem. Field Crops Research, 64: 75-90.

Laheurte F., Leyval I., Berthelin J. 1990. Root exudates of maize, pine and beech seedlings influenced by mycorrhizal and bacterial inoculation. Symbiosis, 9: 111-116.

Li X.L., Christie P. 2001. Changes in soil solution Zn and $\mathrm{pH}$ and uptake of $\mathrm{Zn}$ by arbuscular mycorrhizal red clover in $\mathrm{Zn}$-contaminated soil. Chemosphere, 42: 201-207.

Marschner H. 1995. Mineral Nutrition of Higher Plants. $2^{\text {nd }}$ ed. Academic Press, London, UK.

Mohammad M.J., Malkawi H.I., Shibli R. 2003. Effects of arbuscular mycorrhizal fungi and phosphorus fertilization on growth and nutrient uptake of barley grown on soils with different levels of salts. Journal of Plant Nutrition, 26: 125-137.

Nadian H., Smith S.E., Alston A.M., Murray R.S. 1997. Effects of soil compaction on plant growth, phosphorus uptake and morphological characteristics of vesicular-arbuscular mycorrhizal colonization of Trifoliun subterraneum. New Phytologists, 135: 303-311.

Peterso R.L., Massicotte H.B. 2004. Exploring structural definitions of mycorrhizas, with emphasis on nutrient-exchange interfaces. Canadian Journal of Botany, 82: 1074-1088.

Phillips J.M., Hayman D.S. 1970. Improved procedure for clearing roots and staining parasitic and VAM fungi for rapid assessment of infection. Transactions of the British Mycological Society., 55: 158-161.

Purakayastha T.J., Chhonkar P.K. 2001. Influence of vesicular-arbuscular mycorrhizal fungi (Glomus etunicatum L.) on mobilization of $\mathrm{Zn}$ in wetland rice (Oryza sativa L.). Biology and Fertility of Soils, 33: 323-327.

Shenoy V.V., Kalagudi G.M. 2005. Enhancing plant phosphorus use efficiency for sustainable cropping. Biotechnological Advances, 23: 501-513.

Smith S.E., Read D.J. 1996. Mycorrhizal Symbiosis. $2^{\text {nd }}$ ed., Academic Press, London.

Solaiman M.Z., Harita H. 1996. Effectiveness of arbuscular mycorrhizal colonization at nursery stage on growth and nutrition in wetland rice (Oryza sativa L.) after transplanting under different soil fertility and water regimes. Soil Science \& Plant Nutrition, 42: 561-571.

Yoshida S., Forno D.A., Cock J.H., Gomez K. 1972. Routine methods of solution culture for rice. In: Laboratory Manual for Physiological Studies of Rice. $2^{\text {nd }}$ ed. The International Rice Research Institute, Philippines. 